\title{
Manejo de la mucositis oral en pacientes que reciben quimioterapia, radioterapia o quimioradiación
}

\author{
Lili Ana Ordonez Espinoza, ${ }^{1, a, b}$ Nilton Raúl Velásquez De la Cruz ${ }^{2, c, b}$
}

Ordonez ELA, Velásquez DNR. Manejo de la mucositis oral en pacientes que reciben quimioterapia, radioterapia o quimioradiacción. Cuid salud, ene-jun 2017; 3(1):308315.

\section{RESUMEN}

La mucositis oral es exclusivamente la inflamación y ulceración de la mucosa bucal, secundario a tratamiento anticancerígeno y ocurre en el $40-90 \%$ de pacientes. Ocasionando atrasos, suspensiones o reducciones en la intensidad del tratamiento; disminuye el control de la enfermedad y aumenta la morbimortalidad. Se trata de un artículo de actualización que revisa el manejo de la mucosistis oral secundaria a tratamiento quimio/radioterapeútico o ambos.

Palabras clave: neoplasias, estomatitis, prención secundaria, terapia (Fuente: DeCS BIREME).
Ordonez ELA, Velásquez DNR. Management of oral mucositis in patients receiving chemotherapy, radiotherapy or chemoradiation. Cuid salud, ene-jun 2017; 3(1):308-315.

\section{ABSTRACT}

Oral mucositis is exclusively inflammation and ulceration of the buccal mucosa, secondary to anticancer treatment and occurs in $40-90 \%$ of patients. Causing delays, suspensions or reductions in the intensity of the treatment; decreases the control of the disease and increases morbidity and mortality. This is an update article that reviews the management of oral mucosistis secondary to chemo / radiotherapy treatment or both.

Keywords: Neoplasms, stomatitis, secundary prevention, therapy (Source: MeSH NLM).

Instituto Nacional de Enfermedades Neoplásicas-MINSA.

Instituto Nacional Cardiovascular-EsSalud

a Magister en Enfermería.

a Doctoranda/o en Enfermería por la Universidad Nacional Mayor de San Marcos-Lima.

a Licenciada en Enfermería. 